\title{
The Forgotten History of Food Security in Multilateral Trade Negotiations ${ }^{1}$
}

\author{
Matias E. Margulis \\ University of Stirling \\ m.e.margulis@stir.ac.uk
}

\begin{abstract}
Food security emerged as a major source of political deadlock in the WTO Doha Round negotiations. Concerns about food security only intensified at the WTO following the 2008 Global Food Crisis, with the Bali and Nairobi Ministerials revealing polarized views between the US and India on the financing of public food stockholding. These "food fights" at the WTO have attracted significant international media, civil society and scholarly attention. In this article, I argue that inter-state disagreement on food security is not new or specific to the Doha Round but instead has been a recurrent phenomenon in the multilateral trade system for decades. Employing an historical approach, I show that food security has repeatedly been an item of negotiation in successive GATT negotiating rounds and has been steadily codified in international trade law over time. Today, food security is deeply integrated into the rules of the trade regime, making the WTO an important yet largely unacknowledged institution in global food security governance.
\end{abstract}

\footnotetext{
${ }^{1}$ I am thankful to the two anonymous reviewers, the editor, Kristen Hopewell, William Coleman, Tony Porter and Robert O’Brien for helpful comments. All errors remain my own.
} 


\section{Introduction}

Food security has been among the most contentious issues in the WTO Doha Round negotiations. Such a situation was not envisaged when the Doha Round began in 2001. Food security issues were expected to be minor items, with WTO members setting out to consider the well-known concerns of a subgroup of net-food importing developing countries and tightening up rules on international food aid (FAO, 2003; Clapp, 2004: 2013). Following the 2003 Cancun Ministerial, new food security concerns were added to the agenda. These new concerns were raised in the context of negotiations of the Special Safeguard Mechanism (SSM), intended to address import surges and to protect food security and rural livelihoods in developing countries. Food security concerns were also raised on the negotiation of Special Products, which would permit developing countries to undertake lower tariff reduction on agricultural products critical for national food security. The SSM, in particular, has been a major source of disagreement between developed and developing countries. The lack of consensus on how this agricultural safeguard should be designed and implemented was the key contributing factor behind the breakdown of the Doha Round negotiations in 2008 (Wolfe, 2009).

The 2008 Global Food Crisis intensified the debate on food security at the WTO. The crisis, which was characterized by high and more volatile food prices, prompted debate among WTO members over whether existing trade rules were sufficiently flexible for countries to pursue agricultural policies to ensure food security (De Schutter, 2011; Lamy, 2011; Häberli, 2012; Matthews, 2014; Margulis, 2014a; Farsund et al., 2015). The widespread use of agricultural export prohibitions and restrictions by several WTO members undermined many states' confidence in the ability of international trade to ensure their national food security (Cardwell and Kerr, 2014; Murphy, 2015). At the 2011 Ministerial in Geneva, WTO members discussed the possibility of a new work program on food security, including financial support for net-food importing and least developed countries (LDCs) to address their concerns about high and volatile food prices. Yet at that Ministerial, members were unable to agree on proposed rules to address concerns about the rising use and non-reporting of agricultural export prohibitions and restrictions, demonstrating the widening rift among members on how best to address food security concerns within the trade regime (Margulis, 2014b). Disagreements on how to address food security were also behind the high stakes showdown between the United States and India on 
the purchase of staple foods at administered prices for public stockholding at the 2013 Bali Ministerial; once again, WTO members were wide apart in their views on which additional trade flexibilities and exemptions should be provided to developing countries to address food security (Wilkinson, Hannah and Scott, 2014; Stewart and Bell, 2014; Kripke, 2015). At the 2015

Ministerial Meeting in Nairobi, WTO members once found agreement elusive on two prominent food security issues: a permanent solution to ensure India's national food stockholding programs would be free from legal challenge and how to operationalize the SSM.

There is a demonstrable pattern of increased focus on, and repeated breakdown in, the WTO negotiations over food security issues. This suggests that a lack of agreement among participants on how best to address food security concerns has emerged as a major stumbling block to the conclusion of the Doha Round. Inter-state disagreement over food security issues at the WTO has also become an increasingly high profile issue. These new "food fights" at the WTO have attracted significant scholarly, media, and civil society attention, especially since the 2008 Global Food Crisis, when global food security became a priority issue in world politics and international cooperation (Clapp and Cohen, 2009; Margulis 2009; 2013).

In this article, I argue that inter-state disagreement on food security is not new or specific to the Doha Round but instead has been a recurrent phenomenon in GATT multilateral trade system. I show that food security has been a long-standing point of contention in negotiations and one which has frequently eluded agreement. The bargaining history of food security in the GATT has been under-analyzed and thus the purpose of this article is to illuminate the present by providing a longer historical perspective. In a similar methodological vein to recent studies seeking to provide a fuller account of the GATT's history (see Pauwelyn, 2005; Wilkinson and Scott, 2008; Scott, 2010; De Souza Farias, 2013; Lamp, 2015), I support my claims by drawing on the historical record of past GATT negotiations in order to trace the history of food security in the multilateral trading system. ${ }^{2}$

I develop four interrelated points based on a historically-informed analysis of food security in GATT multilateral trade negotiations prior to the Doha Round. First, nearly every

\footnotetext{
${ }^{2}$ The primary sources for this research are publicly available archives of GATT negotiations obtained from the GATT digital library hosted by Stanford University and the archives of the UN Food and Agriculture Organizations and UN Conference on Trade and Development. In addition, I draw on semi-structured interviews of current and past senior GATT and national trade officials.
} 
GATT trade round that involved negotiations on agriculture dealt with some sort of food security dimension. Second, the history of food security in the multilateral trading system begins much earlier than the conclusion of the Agreement on Agriculture in the Uruguay Round and the creation of the WTO. I show that food security has a rich and extensive history in the GATT and has been a contested issue since the origins of the trade regime in 1947. Taking a longer-term historical perspective, I chronicle how food security concerns have repeatedly arisen in multilateral trading negotiations and how such concerns have been framed and addressed by states in different ways over time.

Third, a recurring pattern of conflict is evident in the negotiations on food security in the multilateral trade system, with a significant divide between agricultural exporting countries and net-food importing countries. Agricultural exporting countries have consistently advanced positions promoting the liberalization of food imports. In sharp contrast, net-food importing countries have sought additional flexibilities for agricultural commodities perceived as vital to national food security and for compensatory financing measures to address concerns about potentially higher food prices. These diverging views on trade and food security remain a persistent source of disagreement among states in the context of multilateral trade negotiations on agriculture. Fourth, many of the specific food security issues that have been most controversial in the WTO Doha Round - such as agricultural export restrictions, special safeguards and food stockholding - are not in fact "new" negotiating items but issues that have been raised in the past and the subject of considerable debate in previous GATT negotiations. To provide an illustrative example: agricultural export restrictions, which were widely used during the 2008 Global Food Crisis and generated heated debate at the WTO, were similarly a major issue for the trade regime during the 1940s and 1970s. Many of the hot button issues in the Doha Round can thus be considered old wine in new bottles.

The article is organized as follows. The next section examines changing conceptions of food security in global governance since the end of the Second World War. I then provide a historical analysis charting how food security has been incorporated in the trade system since its earliest days. First, I consider the food security provisions negotiated in the Havana Charter and the elements that were later incorporated into GATT 1948. I then turn to analyzing engagement with food security issues over the course of four sets of GATT trade negotiations: the Dillon 
Round (1960-61), Kennedy Round (1963-67), Tokyo Round (1973-1979), and Uruguay Round (1986-1994). The last section provides conclusions and reflections on the forgotten history of food security in the multilateral trading system.

\section{Food Security in Global Governance ${ }^{3}$}

The prevailing understanding of food security as an issue in global governance has evolved over time, in parallel with advances in knowledge and technology, changing conditions in the world economy and corresponding changes in the interests and preferences of national and international policymakers (Shaw, 2007; Candel, 2014).

One of the principal objectives of the post-war international system was to eradicate hunger. The architects of the post-war system held a conviction about the international community's collective responsibility to fight hunger and a belief in the vast potential for advances in nutrition and agricultural science to achieve this end. In this context, they created the Food and Agriculture Organization (FAO) in 1945, the first United Nations (UN) specialized agency, to raise world nutrition levels and improve food production and distribution. By the late 1940s, the FAO began work on the international coordination of grain production and trade in order to stabilize food prices and redistribute surplus food produced from the West to meet the needs of the hungry in the developing world. However, this effort came to an end when the US and UK withdrew support for an internationally managed food supply scheme (Staples 2003; Shaw, 2007).

Concerns about a potential world shortage of food emerged in the 1960s, largely prompted by a Malthusian reading of the combination of rapid population growth and lagging food production in developing countries. Western states established the UN World Food Programme (WFP) to provide food assistance to developing countries. A key mechanism enabling international food aid was the burden-sharing system established under the 1967 Food Aid Convention, which was a product of GATT negotiations on agriculture (discussed below). In addition to food aid, developed countries during this period scaled-up bilateral and multilateral assistance to foster food production in developing countries by financing technological transfers

\footnotetext{
${ }^{3}$ This section builds on Margulis (2013).
} 
and the introduction of higher-yield seed varieties, fertilizers and pesticides (i.e., the first "Green Revolution"). While such food assistance served multiple humanitarian and trade objectives for donors, this was a significant development in the evolving practice for world food security because it further concretized the norm of, and expectations for, international cooperation on hunger.

The term food security first entered the policy lexicon during the 1970s in the context of an unexpected shortage of wheat in 1973 that drove international grain prices skywards and caused panic on markets. This was the first officially recognized World Food Crisis. The crisis revealed both a new driver of hunger - price volatility - and that international food markets would not always ensure adequate supplies. The events of the 1970s challenged assumptions about how world food markets worked and drew attention to the need for new instruments of international cooperation to eradicate hunger. Governments met at the 1974 World Food Conference and agreed to deepen cooperation, including establishing new bodies such as the International Fund for Agriculture Development (IFAD) and Committee for World Food Security to address the new drivers of food insecurity (UN, 1974). Although the World Food Conference produced political consensus on the need to address food security, the return of stability to international food markets soon after diminished the sense of urgency for major reform. Despite this shift of attention, the conference's longer-term impact was to establish international consensus on the need for an "international agricultural policy" (Josling, 1985: 274).

The concept of food security continued to evolve, incorporating advances in the understanding of the causes of hunger. In particular, the work of Nobel Prize winning economist Amartya Sen - which demonstrated that access to food, and not just food supply, was critical to averting famine - reoriented international policies to look beyond traditional food production and supply issues (Drèze and Sen, 1991; FAO, 2003b). This new conception of food security recognized various dimensions - supply, availability, utilization, and access - and initiated a major rethinking of international food security policies away from the old approach of traditional bulk transfers of food supplies towards incorporating a set of more targeted interventions (i.e., directed at challenges facing poor households and with a focus on livelihoods) (Maxwell and Slater, 2003). In addition, food security came to be seen as part of a wider package that extended 
beyond calories consumed to include adequate nutrition and access to clean water (PinstrupAndersen, 2009). This multifaceted understanding became the basis of the current international consensus definition of food security negotiated by states at the 1996 FAO World Food Summit, which remains today the accepted basis for international and national food security policymaking. ${ }^{4}$ At the 1996 Summit governments committed to reduce world hunger by half. This commitment became the later basis for the first Millennium Development Goal to reduce the number of hungry people by half by 2015 . Governments have subsequently increased this ambition in the Sustainable Development Goals by calling for an end to hunger by 2030 .

Taken together, these developments shaped the construction of food security as an issue area for international cooperation. The desire to eradicate hunger alongside an evolving understanding of food security was reflected in changing institutional arrangements and governance practices. This wider context is important for understanding the bargaining history of food security in the GATT/WTO.

\section{The International Trade Organization and GATT 1948}

I start with examining food security issues in the context of the UN negotiations on the Havana Charter for the International Trade Organization (ITO) in 1947. Agriculture and food security concerns weighed heavily on the minds of the architects of the post-war economic order. An acute policy concern was the inability of Europe to feed itself and the threat this situation posed for peacetime reconstruction. In addition, the US required Europe and other food importing countries to absorb its surplus agricultural production. However, this situation was a source of growing commercial tensions between the US and other major food exporters such as Canada, Argentina, and Australia, with the latter seeking to maintain their access to the European market.

Agricultural trade was a major part of the Havana Charter negotiations (UN, 1948a). In the 1940s, agriculture continued to be a significant economic sector and source of employment, production, and foreign exchange for both developed and developing countries. The vision for the ITO was to increase trade in agriculture but to retain many flexibilities, especially for developing countries (Hudec, 1987; Onyejekwe, 1993).

\footnotetext{
${ }^{4}$ The current definition is: "Food security exists when all people, at all times, have physical, social, and economic access to sufficient, safe and nutritious food which meets their dietary needs and food preferences for an active and healthy life."
} 
The Havana negotiations addressed multiple food security issues. Among these was the use of unilateral food export prohibitions and restrictions. This was a sensitive political issue due to wartime experiences where food shortages and rationing had been common. There was an expectation among states that the new peace situation would permit a resumption of food production in Europe and normal trade in food. However, the inherent volatility of agricultural production meant that importing states remained concerned that major producing countries could still resort to agricultural export restrictions, which could lead to critical shortages of food and non-food commodities on international markets. Such situations were a source of considerable international political tension (and had been during the war). International cooperation on export restrictions and prohibitions was thus seen as highly desirable by most states, and most acutely by net-food importing countries, to bring order back to food markets.

States therefore agreed under the Havana Charter to permit agricultural export restrictions and prohibitions only on a temporary basis "for the period necessary to prevent or relieve critical shortages of foodstuffs or other products essential to the exporting Member country" (UN, 1948a: 34). The proposed rules on export restrictions recognized the principle that domestic food security came before international trade. However, the proposed rules created a new expectation that export bans would only be undertaken under special circumstances and only on a temporary basis and were, therefore, an aberration from normal trade policy practice. The new international approach to agricultural export restrictions and prohibitions was consistent with how food insecurity was understood during this period. Policymakers regarded hunger as principally a supply problem and international cooperation to diminish the threat of export bans was intended to ensure the smooth flow of food from surplus to deficit countries.

The Havana Charter was also important for food security as it enshrined international cooperation in the management of the world food supply in international law. It is well known that the Charter established the legal framework for the post-war intergovernmental commodity agreements (ICAs), with the impetus to reduce price fluctuations and balance world supply and demand for key food and non-food commodities (UN, 1948a; see also Gilbert, 1997; Raffaelli, 1995). Yet a less appreciated objective of ICAs in the Havana Charter was to achieve food security. While much of the stated rationale for ICAs lay on the premise of achieving "fair" prices for consumers and "remunerative" prices for producers, the Charter also recognized that 
ICAs could play a role in the expansion of consumption of basic foodstuffs. Article 57 (Objectives of Inter-governmental Commodity Agreements) permitted the establishment of ICAs in appropriate cases for "the distribution of basic foods at special prices" (UN, 1948a: 78). The reference in the text to "special prices" means food available at below market prices or on concessionary terms (a practice, for example, consistent with what the US had done for its allies during the war). This objective highlighted post-war concerns and realities of expected food surpluses among the food exporters (who had significantly increased production capacity during the war years) and the difficulties of importing countries to afford sufficient supplies at prevailing market prices. Not only did the Havana Charter provisions on ICAs anticipate this problem, its architects articulated an early recognition by states of an implied obligation for foodproducing countries to distribute food on non-commercial terms. This obligation prefigured the international food aid regime that emerged decades later.

As is well known, the attempt to establish the ITO failed after the US Congress declined to ratify the Havana Charter, jettisoning the idea of a formal international organization with authority to govern international trade until the creation of the WTO in 1995. Instead, states kept some of the provisions from the Havana Charter and incorporated them into the GATT 1948, which became the basis for the post-war international trading order (Krueger, 1998; Drache, 2000).

There were elements of both continuity and change in how food security issues were treated in the Havana Charter and GATT. The GATT mirrored certain provisions in the ITO, such as permitting governments to apply food export restrictions and prohibitions on a temporary basis. Yet, there were also significant differences. While the ITO was intended to cover both the agricultural and industrial sectors and included extensive rules for each, the GATT included few rules on agriculture and in practice, due to the extensive use of exemptions, largely excluded agriculture from international trade disciplines (GATT, 1961a; Trebilcock and Howse, 2005). A key difference was that GATT 1948 did not include ICAs, which had been a central part of the ITO's mandate to coordinate world agricultural supply and trade (Josling et al., 1996). This omission is significant for understanding how the relationship between trade and food security was envisaged because a key objective of the Havana Charter had been to make foodstuffs available at below market prices through ICAs. With the failure of the ITO, the initial 
momentum dissipated for an international trade mechanism intended to make food more affordable for food importing countries.

\section{Pre-Uruguay Round GATT Negotiations}

In this section I demonstrate the decades long history of food security in the GATT prior to the Uruguay Round. I do this by charting how food security issues have been raised, framed, and negotiated in the GATT. This includes analysis of food security-related bargaining proposals introduced by the contracting parties ${ }^{5}$, the evolving negotiation agenda, and inter-state negotiation dynamics. Under consideration are both cases of completed bargains on food security arising from GATT negotiations (such as the conclusion of new agreements, trade rules, governance practices, and/or international policy instruments), as well as instances of nonagreement. It is important to consider non-agreement in the negotiations alongside agreement because the former informs about key issues on the agenda for which consensus proved too difficult. Non-agreement can also influence the course of future events, if for example, a nonagreement becomes the source of unresolved political tension that can come to shape inter-state relations over longer time horizons. This is especially important in multilateral trade negotiations given their iterative quality; repeated interaction among states over successive negotiation rounds means that past events shape the future. It will be shown that negotiations on food security has been an ongoing subject of multilateral trade negotiations, resulting in agreement and nonagreement at the GATT.

\section{The Dillon Round (1960-62)}

GATT contracting parties pursued substantive negotiations on agriculture in the Dillon Round. The main impetus for launching the Dillon Round was the establishment of the European Economic Community (EEC) in 1957. The US demanded a new round in order to conclude tariff negotiations in advance of the EEC's common external tariff taking effect in 1962 (US, 1958). The liberalization of agricultural trade, alongside the reduction of industrial tariffs and the incorporation of newly independent developing countries, were the core issues on the negotiating

\footnotetext{
5 A point of clarification - "Contracting Parties" refers to states party to the GATT. This is equivalent to the term "WTO Members" that similarly refers to states or custom unions that have acceded to the WTO.
} 
agenda. With respect to agriculture, GATT contracting parties had agreed to consider "problems arising out of the widespread use of nontariff measures for the protection of agriculture, or in support of the maintenance of incomes of agricultural producers" (GATT, 1958). Contracting parties were principally focused on the negative effects that import barriers and price supports had on the level and patterns of international agriculture trade (Hoekman and Kostecki, 2001).

Food security issues were not initially on the negotiating agenda; however, as the negotiations advanced, the intertwined issues of agricultural surpluses and food aid took on significant importance. The disposal of agricultural surpluses as international food assistance, especially by the US, was already by this time a major source of trade tensions among agricultural exporters. Canada and Australia, for example, regarded existing international rules to minimize food aid's distorting effects on commercial agricultural trade in the 1954 FAO Principles on Surplus Disposal as insufficient. These countries were especially concerned with the market development element of US food aid.

This was a period of expansion of the use of food surpluses for humanitarian assistance and to promote economic development in developing countries. The UN had just agreed to set up a temporary world food agency intended to increase the provision of food aid. In this context, food exporters (not food importers) pressed for stronger rules to prevent commercial displacement. Contracting parties agreed to add agricultural surpluses to the negotiation agenda in 1961. The negotiations on agricultural surplus disposal involved consultations with the FAO and other international organizations to provide information on international food security developments. The chair of the negotiations concluded that a key issue facing the Contracting Parties was how to dispose of surpluses given the limited purchasing power of poor countries and thus "the extent that governments are able to make available their abundance of food to lowincome food deficit countries on a grant basis or on other concessional terms without displacement of normal commercial trade, and to the extent that such food can be directed into additional total consumption" (GATT, 1961b: 10). In other words, the question was how to balance trade versus aid concerns.

The Dillon Round is notable as it saw the emergence of food exporters' critique of surplus disposal in trade negotiations. Wheat exporters such as Canada, Australia and Argentina drove and shaped this critique. They accused the US of dealing with its domestic wheat 
overproduction by subsidizing non-commercially viable exports as food aid and were particularly concerned by the US' expansion of long-term concessionary sales of wheat on credit as food assistance. Given that wheat was the most important food grain in the world food economy of the time (Friedmann, 1982), exporters' primary concerns were the impacts that surplus production/food had on depressing international wheat prices and the competitiveness of their exports. The consideration of developing countries' food needs was secondary to concerns about lost market share. An extensive review of Contracting Parties' agricultural policies during the negotiations revealed this critique with the chair of the negotiations stating:

Wheat provides the best example of the effect on international trade of price support measures causing export surpluses leading to pressures for disposal on subsidized or concessional terms...In its Review of the World Wheat Situation of April 1960, the International Wheat Council found that total wheat and flour exports covered by special governmentally assisted export programmes made up nearly $28 \%$ of world wheat and flour exports. Indeed, since about 1953 a fairly important increase in the world trade in wheat and flour has been almost entirely due to non-commercial transactions which have made possible increased consumption. (GATT, 1961b: 5-6)

Food exporters' critique of surplus disposal framed the discussions on food security in the Dillon Round. The same critique would also reappear and shape negotiations on food security issues in subsequent GATT trade rounds.

Interestingly, it was not the developing countries, the main recipients, who raised concerns related to food aid. Robert Hudec (1987: 44-46) argues that developing countries were single-mindedly focused on the removal of trade barriers by developed countries in the round. The Dillon Round was seen by the GATT as an opportunity to address the specific problems identified in the 1958 Haberler Report, which had confirmed that the terms of trade for developing countries had deteriorated and supported the inclusion of special and differential treatment in the trade regime (Hudec, 1987; Toye and Toye, 2004; see also Lamp, 2015).

The Dillon Round failed to achieve a broad agreement. In the case of agriculture, limited progress was made on addressing import barriers. However, the US negotiated with the EEC for 
duty-free bindings on soybeans, linseed, flaxseed, oilseed meal, and cotton, which was seen as a major triumph (Finger, 1974). However, contracting parties agreed that agricultural surpluses would be the subject of future GATT negotiations and notably provided the GATT with a new surveillance function for international food aid. Whereas such a role had been previously the exclusive domain of a FAO subcommittee on surplus disposal, a trial monitoring mechanism for

surplus disposal was initiated with the expectation that contracting parties would report details of their policies and provide a detailed record of all food surplus transactions to the GATT Secretariat. This marked a shift in the trade regime's approach to food security with the GATT delegated authority to monitor states' food security policies.

In sum, food security was negotiated in the GATT Dillon Round. Contracting parties debated issues concerning the supply-side of international food assistance, which was consistent with the understanding of food security at the time as primarily a supply issue, and concerns about the trade distorting effects of food aid in a substantive manner in the context of multilateral trade negotiations for the first time. States also delegated new functions to the GATT to monitor international food aid.

\section{The Kennedy Round (1963-1967)}

Food security was prominent in the Kennedy Round negotiations. At the outset of the round, contracting parties differed in their concerns and positions over which world food problems might be addressed in the GATT (Rehm, 1968; Norwood, 1969). The principle world food problems at the time were linked to concerns about rapid population growth and declining per capita food production in developing counties that were predicted to create widespread food shortages and political instability, especially in India (Koffsky, 1967). This was also a period of major expansion of bilateral food assistance programs by developed countries, but also the tightening of world grain supplies after years of gluts on international markets.

Another new and important political dynamic was that developing countries were increasingly disaffected with the GATT. Primarily through the work of the Group of 77 (G77), developing countries convened the UN Conference on Trade and Development (UNCTAD) in 1964 in order to address their trade-related concerns. This included the negotiation of new preferential and commodity agreements (Toye and Toye, 2004). The creation of UNCTAD 
meant that the GATT was no longer the only game in town when it came to multilateral trade negotiations. This development marked a shift in the GATT's policy towards developing countries, including a greater effort to seriously address developing countries' demands for improved market access (Hudec, 1987:55-58). This was a historical moment of great uncertainty and contestation over the future shape of the multilateral trade system.

According to Irwin Hedges (1967), who advised the US government during the negotiations, there were four main objectives with respect to agriculture: 1) increase grain exporters' access to EEC markets; 2) renegotiate an international floor price for wheat; 3) adjust global wheat supply in line with growing world commercial and non-commercial demand; and, 4) establish a multilateral food aid program. Contracting parties also engaged in extensive discussions about the strategic use of grain surpluses with the view of better coordination of domestic policies to reduce volatility in international grain prices (GATT, 1962). The round was characterized by the US and EEC at loggerheads on how to achieve price and supply stability. The EEC proposed the measuring and binding of all support to agriculture (i.e., montant de soutien), whereas the US pressed for major agricultural tariffs reductions (Josling at al., 1996: 62-66).

A key food security item on the agenda of the Kennedy Round was the issue of food selfsufficiency in the context of negotiations to manage international grain supplies. Food exporters were keen to establish a world supply management scheme for grains as part of a broader strategy to discourage the UK and France from moving towards a policy of food self-sufficiency (Hedges, 1967). By the mid-1960s the UK and EEC nations, the latter only recently starting to operate under the new Common Agriculture Policy (CAP), were in a process of building up their support price schemes to expand domestic grain production. Achieving agricultural selfsufficiency was a food security policy objective of the CAP. However, EEC policy to ramp up domestic food production had the effect of increasing competition in international grain trade, with food exporting countries finding their access to the Western European market shrinking. During the negotiations, the EEC proposed incorporating a self-sufficiency ratio into GATT rules. A self-sufficiency ratio establishes the relative proportion of domestic production and foreign imports that make up total food consumption; in the context of the GATT, this would have served as the basis for the EEC to set the total volume of agricultural imports permitted into 
its market. The EEC proposal was intended to lock in its ability to provide support and to address food exporters' concerns of access to the European market by guaranteeing them a fixed proportion of the market.

Contracting parties established a "Wheat Group" to facilitate negotiations on the EEC's food self-sufficiency policy. The group included developed country exporters such as the US, Canada, Australia and one developing country exporter, Argentina. Food importing developing countries were excluded and this led to complaints by India (1967) about the negotiation process. During the talks, the EEC proposal of binding self-sufficiency at $90 \%$ was not regarded by exporters as a satisfactory offer. After two years of negotiations, the EEC proposal to lock in food self-sufficiency ratios was eventually withdrawn but without reaching a broad agreement on agricultural market access. Instead, negotiations shifted its focus to work on an international agreement for wheat (US, 1966; Josling et al., 1996: 65-67).

The most significant development in the Kennedy Round for world food security was the proposal by grain exporters to establish permanent international mechanisms for food aid. By 1964, states had already been discussing the creation of a permanent multilateral food aid program at the UN. These discussions also took place at the GATT. The US called for the negotiations to include talks on the orderly disposal of surpluses for food assistance through multilateral channels, including the suggestion that importers in addition to exporters contribute food. In other words, the US pressed for a burden-sharing approach to international food aid. Argentina circulated a proposal that called for the establishment of a multilateral food fund made up of cash and in-kind food donations. The stated purpose of this fund was to expand multilateral hunger eradication efforts, but also to counteract the depressing effects of bilateral food aid on world prices (Argentina, 1965). The competing logics of humanitarian, trade and foreign policy objectives were evident in the GATT negotiations, where the idea of a burden-sharing system meant:

Food aid contributions were viewed primarily as one of the means of achieving the objectives of access and joint participation in supply management. A food aid program to which both exporters and importers pledge specific contributions would provide an outlet for excess production and help strengthen and stabilize commercial 
grain markets. At the same time it would represent a beginning toward a more equitable distribution of the burden of meeting the food aid requirements of developing nations. (Hedges, 1967: 1335)

Contracting parties achieved consensus on an approach to govern multilateral food aid. This would result in significant changes in the way in which states dealt with world food supply management.

The Kennedy Round negotiations resulted in two important and interrelated international agreements: the Wheat Trade Convention (WTC) and the Food Aid Convention (FAC). The WTC established floor and ceiling prices for wheat, and intended to more smoothly manage international wheat production and prices. The FAC committed states to providing a fixed quantity of grains (mostly wheat) as international food assistance and set out international best practices and a reporting and monitoring mechanism for international food aid flows (GATT, 1967). The WTC and FAC were seen by states as a solution for managing the international wheat market, while simultaneously ensuring surpluses were disposed of as food aid with the least distortions to commercial trade.

It is important to emphasize that the general framework and main provisions of the WTC and FAC were negotiated during Kennedy Round negotiations. Only once contracting parties had agreed on the key elements that the finishing touches on the WTC took place at the International Grains Council. Similarly, the FAC was later shifted to the FAO for the completion of operational details prior to its ratification under the UN system as an international treaty only after the key issues were settled in GATT negotiations. Both the WTC and FAC were plurilateral agreements and included all the major grain exporters and importers: Argentina, Australia, Canada, Denmark, Finland, Japan, Norway, Sweden, Switzerland, the UK, US, and EC. These countries were the most important countries in the world wheat market except for the Soviet Union, which was not a part of GATT negotiations. This group of signatories satisfied the US's demand for a burden-sharing approach to food assistance.

The GATT Kennedy Round's importance for world food security has been all too often underestimated. The round resulted in inter-state agreement on a minimum level of international food aid commitments in the form of annual quantitative pledges by a subset of contracting 
parties. It moved the food aid system toward greater predictability of supply and accountability of donors. The FAC provided (at least until quite recently) assurance of stable grain supplies that the WFP could expect to draw on for its food assistance activities. Although the Kennedy Round did not result in new GATT rules on agriculture, the GATT was the forum in which states negotiated the basis of the emerging international food aid regime. In other words, the Kennedy Round negotiations demonstrate the GATT's role as a key forum for inter-state negotiations on food security issues of that time.

\section{The Tokyo Round (1973-1979)}

Agriculture was front and center on the negotiating agenda in the Tokyo Round, which called for the Parties to "take account of the special characteristics and problems in this sector" (GATT, 1973b: 4). The objectives of the round were to address tariff escalation and non-tariff barriers across industrial goods and commodities, including agricultural goods. The GATT Tokyo Round is particularly relevant to food security for several reasons, including: 1) the addition of food security to the agenda after the round began due to external real world events; 2) the initiation of a GATT-led process to clarify the relationship between food security and trade rules; and, 3) the consideration of an international food supply management scheme to ensure food affordability.

The timing of the Tokyo Round is important as the negotiations were just getting underway when the World Food Crisis struck. That crisis, similar to the recent Global Food Crisis, led to a sharp and swift rise in grain prices and panic on world markets. States resorted to food export restrictions and prohibitions. The US enacted a soy bean export, initially starting with an all-out ban before shifting to a system of export controls, in order to address domestic food price inflation and consumer pressure (Friedmann, 1982). Net-food importing developing countries, also severely affected by high oil prices at the time, found their food imports threatened by severe balance of payments difficulties.

While the world food security problem was not initially on the negotiating agenda for the Tokyo Round, once the magnitude of the food crisis was apparent, it became a major item of discussion among the contracting parties. Concerns over tight international food supplies, and the implications for agriculture trade and international political stability, elevated food security to a major item on the negotiation agenda. 
At the first meeting of the Trade Negotiations Committee in 1973 to set the agenda, contracting parties discussed the relationship between the round and the upcoming FAO World Food Conference intended to address the food crisis. In his first report to the Trade Negotiations Committee, the chair of the GATT group on agriculture had identified that "there may be special problems affecting trade in certain commodities, such as those relating to food security, which may also require special attention" (GATT, 1974d: 6). This implied that contracting parties were well aware of the linkages between trade in agriculture and world food security. At this meeting, the US (a strong supporter of the FAO-led World Food Conference) clarified that the GATT was the only forum where trade commitments could be negotiated to address the trade-related aspects of the world food problem. The US did not see the need for shifting agriculture trade issues into the UN; rather, the US regarded the work of the GATT negotiations and FAO as complementary (GATT, 1973a).

Once the Tokyo Round negotiations were underway, the contracting parties tasked the GATT Secretariat to produce studies on agriculture production, trade, and consumption patterns. This work sought to improve their understanding of the trade-related dimensions of world food supply and provide a basis for future decisions on agricultural trade liberalization (GATT, 1974a, 1974c, 1974d, 1974b, 1974e). Trade negotiators continued to view the problems in terms of an undersupply of food, even though the Rome-based discussion at the FAO had started to broaden out to also encompass food price volatility and speculation. Contracting parties did not share a consensus view on the causes of the World Food Crisis, which became an increasing point of tension in the negotiations.

In order to facilitate discussions on agricultural trade and the world food problem, all delegations were requested by the GATT Secretariat to submit in writing their views on the causes of, and conclusions to be drawn from, the changes in world agricultural markets (GATT, 1974b). Contracting Parties' submissions to the GATT revealed diverging views with respect to the role of the GATT and trade policy in addressing world food security. The US was of the view that agricultural trade liberalization and greater interdependence were necessary to overcome the boom and bust cycle of agricultural prices, which it argued posed a threat to world food security (US, 1974). Other exporters identified the food self-sufficiency policies of the EEC and other 
countries as having depressed world agriculture prices in the years prior to the crisis and having made international markets less responsive. The latter position was expressed as follows:

Among the contributory factors underlying and aggravating the present shortages were the policies which created uncertainties in the market. Without some certainty of access to markets, there was little incentive to increase production. Agricultural production cannot be turned on and off like a tap in response to stop-go measures taken by governments. While it might not have been possible to avoid shortages altogether, their impact might have been lessened had the supplying countries had security of access. The last few years had shown that when prices exceeded certain levels, protective devices became unnecessary and had in certain instances been relaxed or suspended by some major importers. Thus, if world prices were at or above remunerative levels, bigger trade flows resulted. On the other hand, account must also be taken of consumer reaction to high prices leading to decreased demand, and of rapid price fluctuations which generate uncertainties for producers. (GATT, 1974e: 3$)^{6}$

Contracting parties spent considerable time debating the causes and consequences of the food crisis during the negotiations. They disagreed on whether the crisis was temporary or likely to be long lasting and on the feasibility of various proposals for increased international cooperation on food security.

Despite diverging positions on the causes of the food crisis, there appeared to be consensus towards the desirability of some form of international supply management for key grains such as rice (echoing earlier failed efforts during the Kennedy Round). Canada, for example, proposed that contracting parties undertake substantive reforms to ensure the "security of supply of agricultural products at reasonable prices" (Canada, 1974: 2). In order to further explore the international supply management scheme, a "Sub-Group on Grains" was formed and delegated to further work on the issue. Unlike the Wheat Group of the Kennedy Round that was

\footnotetext{
${ }^{6}$ This statement was not officially attributed in the GATT report to a specific contracting party but it was likely made by a food exporter such as Canada, Australia or Argentina.
} 
limited to food exporters, the Sub-Group was more inclusive and involved forty contracting parties. These ranged from developed to developing countries and food exporters to importers. The GATT also invited UNCTAD, which continued to work on ICAs, as an official observer to the talks (GATT, 1975a).

Two competing approaches to international food supply management dominated the work of the Sub-Group on Grains throughout 1975 and 1976. Food exporters stated their priority was liberalizing trade in grains. This met with some resistance from the EEC, which highlighted instability in grain markets as the central world food problem rather than the lack of liberalization (EEC, 1975). Developing countries, in contrast, wanted consistency between the GATT negotiations and the emerging world food security agenda coming out of the UN on ensuring food affordability. Developing countries in their intervention had,

[E]mphasized the need for ensuring the security of supplies at reasonable prices for importing developing-countries, taking specially into account the needs of the most seriously affected countries....including measures being discussed in the International Wheat Council and in the framework of the International Undertaking on World Food Security in pursuance of the decisions of the [UN] World Food Conference. (GATT, 1975b: 1)

Hardening positions on grains trade become increasingly evident as the Tokyo Round progressed. On the one hand, a negotiation bloc formed among the EC, Japan, and developing countries that pushed for international grain management, while on the other hand, the US argued strongly for addressing agricultural market access, export subsidies, and safeguards (US, 1975). India pushed for measures to support agricultural production in developed and developing countries and for the establishment of a system of international food reserves and stockholding to ensure affordable food to developing countries (India, 1976).

Diverging positions pointed to a growing disagreement on how to address food security within the GATT negotiations. By the Sub-Group on Grains May 1976 meeting, it was apparent that there was a deadlock on food security with the chair reporting, 
Given the amount of work that remained to be done, and in light of the date now set for the completion of the Multilateral Trade Negotiations, it was noted, with regret, that little progress had been made since the Sub-Group's last meeting in narrowing the differences between some of the major trading countries. (GATT, 1976: 2)

After this meeting, the Sub-Group on Grains did not reconvene for the remainder of the Tokyo Round. The reasons for the collapse of the GATT negotiations on international food supply management were threefold. First, disagreement among the contracting parties over the basic parameters persisted and no suitable compromise emerged. Many governments supported a world supply management scheme for grains while others, notably the US, demanded that the negotiations focus on reducing tariff and non-tariff barriers. Given its pre-eminent role as the world's principle food supplier during this time, the US preferred not to support an outcome that would have been potentially burdensome to it. Its firm position was that an "international trading structure based on liberalized national trade policies is by far the most reliable and efficient basis for ensuring the availability of adequate grain supplies to meet world needs" (US, 1976: 1). As with agricultural issues more generally in the Tokyo Round, a deal was not in the making.

Second, the work of the Sub-Group on Grains overlapped with similar negotiations elsewhere. In order to keep discussions going as momentum faded in the GATT, the work of the Sub-Group was first shifted to the International Wheat Council, which had a mandate to consider international grain trade problems. Later, work on international food supply management was shifted out again as developing countries sought to incorporate multilateral talks on wheat into the negotiations on international commodity agreements underway at the UN Conference to Negotiate an International Arrangement to Replace the International Wheat Agreement of 1971 ( Lamond, 1977; Bergesen, 1980; Cohn, 1979). The failure to find compromise within the GATT, combined with the availability of other forums and the forum-shifting strategies of states, resulted in negotiations on international food supply management being shifted out of the GATT and into other international venues.

Third, world food prices had declined considerably by 1975 and supply conditions improved markedly. Though most prices of foodstuffs remained consistently high until the early 1980s (FAO, 2009b: 11), the relative improvement in world food markets eased the sense of 
urgency that had prevailed during the onset of the Tokyo Round negotiations. Many governments interpreted improving market conditions to mean that the necessity and rationale for investing political capital on international coordination and cooperation for food security was no longer required. As a result of these three factors, negotiations on food security in the GATT came to a halt without consensus among the contracting parties. The lack of consensus on food security and international trade rules would become even more apparent during the Uruguay Round negotiations.

\section{The Uruguay Round: Institutionalizing Food Security in the Trade Regime}

I now turn to how food security issues were negotiated during the GATT Uruguay Round. This round receives additional attention because it marked a turning point in food security's place in the trade regime. Earlier GATT negotiations were characterized by negotiations on food security that eventually shifting out to other international bodies. The Uruguay Round negotiations broke this pattern and instead marked a shift toward the institutionalization of food security issues in a rules-based framework. The Uruguay Round also requires additional attention because its resulting rules formed the basis for the subsequent Doha Round negotiations.

To appreciate the dynamics of the Uruguay Round and how food security was treated in the negotiations, the specific historical state of world agriculture needs to be considered. In contrast to the Tokyo Round that began during an episode of skyrocketing food prices, the Uruguay Round was launched in a period of falling food prices. Declining food prices were the direct outcome of an agricultural export subsidy war between the US and EC. Each engaged in one-upmanship by providing producers, who were sitting on large agricultural surpluses, with direct governmental assistance in order to better "compete" in world markets, but which greatly depressed the prices of agricultural goods and led to domestic farm crises (Wolfe, 1998; Watkins, 1991; Friedmann, 1982). Though export subsidies made food cheap on international markets, they also had the effect of discouraging staple food production in developing countries while also undermining the competiveness of other grain exporters. ${ }^{7}$ Meanwhile, agriculture had come to be viewed by developing country as the "backwards" sector (Hirschman, 1978; Roa

\footnotetext{
${ }^{7}$ For example, in the early 1980s, US and EC wheat entered Mali and Burkina Faso at prices $40 \%$ lower than local grains (GATT, 1993).
} 
1986); many taxed agriculture to fund industrialization, often resulting in policies that were biased in favor of urban over rural populations and that resulted in a prolonged period of underinvestment in agriculture (Krueger et al. 1988; Bezemer and Headey, 2008; Anderson, Rausser and Swinnen, 2013; Hopewell, 2016).

The Uruguay Round also occurred during a paradigmatic shift in economic policy ideas and practice. The 1980s were the period when the "Washington Consensus" emerged as the new dominant paradigm in international economic policy circles, advocating a smaller role for the state in the economy and a greater role for markets (see Williamson, 2009). During this period, the policy consensus shifted towards the reform of developed countries' agriculture policies, with the goal of reducing production and trade distortions (Swinbank and Tanner, 1996; Paarlberg, 1997; Skogstad, 1998; Coleman, 1998). To address soaring national debt and balanceof-payments of problems, developing countries adopted structural adjustment programs involving unilateral tariff reductions in agriculture, a renewed focus on agricultural exports, and the privatization of marketing boards and other state-owned enterprises. In many cases, economic reforms by developing countries included the scaling back of state support for agriculture, including extension services and subsidized inputs for farmers and food subsidies for the urban poor. The dynamics above shaped the economic and political context of the GATT Uruguay Round negotiations on agriculture and food security.

\section{Setting the Negotiation Agenda: Free Trade vs. Food Self-Sufficiency}

Right from the outset of the Uruguay Round, food security concerns featured prominently in the negotiating agenda. The Committee on Agriculture and Trade undertook the task of elaborating the parameters of the future agriculture negotiations for ministerial approval. In addition to the general objective of "bringing trade in agriculture more fully into the multilateral trading system," the Committee recognized the negotiations would need to consider a general declaration on food deficits and the development needs of developing countries (GATT, 1986: 7). This reference to food deficits acknowledged the difficulty developing countries experienced in producing adequate food and/or earning sufficient foreign exchange to purchase food on international markets as a result of the 1980s petro-dollar debt crisis. 
One of the early ideas discussed by the contracting parties in advance of launching the round was whether food security could provide justifiable grounds to invoke and maintain import restrictions and quantitative restrictions, as well as a basis for special and differential treatment (GATT, 1985). Indeed, once the round began, the Committee on Agriculture and Trade considered that guaranteeing food security should be a principal objective of the round and that it should be "taken as a point of departure in determining which rules should govern trade in agriculture" (GATT, 1986c: 33).

Although there was a consensus to bring stability to world agriculture markets, discussions over the unique role agriculture played in national economies exposed diverging views surrounding the extent to which contracting parties were willing to pursue trade liberalization in agriculture and how this was to be linked to food security. The chair of the agriculture negotiations identified two competing schools of thought concerning the relationship between agriculture, food security, and international trade. The first school consisted of states where less favorable production conditions prevailed and where "national policy objectives in the areas of food security, stability of domestic income and price support arrangements and regional development are seen by and large as taking precedence over broader international trade considerations" (GATT, 1986: 26). The other school, he identified, regarded such concerns as incompatible with greater trade liberalization and called for domestic policies to be adapted gradually to "market forces and comparative advantage" (GATT, 1986c: 26-27). This dynamic would come to shape the negotiations with one set of countries more generally supportive of food self-sufficiency and another advocating freer trade in food.

Food security was a pivotal topic scheduled for discussion at the June 1988 meeting of the Negotiating Group on Agriculture (GATT, 1988a). This was a critical point in the Uruguay Round as at this moment the contracting parties were still clarifying their positions and the specific items to place on the negotiation agenda. The US proved to be the first mover on the issue and put forward its position arguing that freer trade in agriculture, rather than food selfsufficiency, was most effective for achieving food security. In its initial agriculture proposal, the US radically called for the elimination of all market access barriers and subsidies (US, 1988). The US argued that food self-sufficiency policies represented an inefficient allocation of resources that distorted world markets and that such policies were incongruent with the "reality" 
of agricultural markets characterized by a growing number of reliable public and private suppliers (US, 1988).

In a response to the US's proposal, developing countries stressed that the primary obstacle to achieving food security was their limited ability to purchase foodstuffs at prevailing world prices. Free trade in food, and the food-import dependency this implied, was viewed by many developing countries as politically unacceptable and as impinging on national sovereignty. Many developing countries were well aware of the commercial interests behind the US position, given its unique position at the time as the world's largest and unrivalled food exporter. Several developing countries called for the right to autonomously determine levels of food production and trade in the face of unpredictable international markets (GATT, 1988c).

Jamaica, a net-food importer and strong voice for smaller developing countries during the round, offered an alternative approach to the US proposal. It advanced a proposal stating that food security could not be realistically divorced from ensuring a minimum level of food selfsufficiency. Jamaica also elaborated the idea of framing food security in the GATT primarily from a developing country perspective and emphasized the need for the round to satisfy the minimum food needs of the poor and undernourished, reduce instability in food supplies and prices, and increase policy autonomy in food production at national, regional and sub-regional levels (Jamaica, 1988).

Other developing countries such as Mexico, Egypt, Morocco, Nigeria, and Peru also raised food security concerns. These countries coordinated their positions in the negotiations to put forward the idea of transitory measures to address the potential impacts of trade liberalization on world markets in a joint agriculture proposal. Their proposal called for the Uruguay Round to address a range of food security concerns, including food aid, compensatory measures for food price increases, greater multilateral financing, investment for agricultural development in developing countries, and balance of payments support under the rubric of food security (GATT, 1988b).

Middle-income and developed food-importing countries also weighed in on the food security debate. South Korea argued for the need to provide food-importing countries with the possibility to maintain a minimum rate of self-sufficiency for national food security (just as the EEC had proposed in the Kennedy Round) alongside trade liberalization commitments (South 
Korea, 1988). Japan's proposal called for the negotiations to address food security as a non-trade concern. Japanese negotiators also stressed the critical importance for net-food importing countries to maintain a minimum level of production of basic food stuffs given their significant vulnerability to the dictates of market swings:

Stable supply of such "basic foodstuffs" is essential for every country from the viewpoint of food security. For countries whose self-sufficiency rate of foodstuffs is particularly low, the need to maintain a stable level of domestic supply is indispensable to safeguarding the livelihood of their citizens. This is a political requirement which transcends a mere logic of economy. (Japan, 1988: 7)

Japan's views on food security reflected its historical experience with food shortages in the postwar era and was informed by the important social and cultural role of rice production. Japan's situation as a major net-food importer made it highly vulnerable to unpredictability in world supply and also to policy swings by food exporters, such as the US's soybean embargo.

Japan's position in the round as a strong advocate for protecting domestic agricultural production for food security put it at odds with many developed and developing countries. In the negotiations, Japanese officials were heavily criticized for taking a protectionist position by developed country food exporters such as the US, Canada and Australia. Many developing netfood importing countries were also critical of Japan because they argued for the need to differentiate between their food security challenges and those of wealthy net-food importers that had the purchasing power to more readily procure food on international markets. Some delegates went so far as to that claim Japan (and South Korea) were "abusing the concept of food security to unnecessarily restrict trade," while others recognized that wealth alone did not guarantee that supplies would be available in times of international conflict or shortages (GATT, 1988c, 2).

Even though the contracting parties were divided on how to specifically treat food security, they agreed that food security would be an integral part of the negotiations on agriculture. The negotiation agenda for the Uruguay Round was formalized at the 1988 GATT Ministerial Meeting in Montreal. Although the term "food security" was not explicitly referred to in the official text of the Montreal ministerial declaration, ministers had agreed to address the 
"possible negative effects" on net food-importing developing countries of trade liberalization as part of the agriculture negotiations (GATT, 1988d: 13).

\section{Negotiating Food Security}

Once the formal negotiations were underway in 1989, the politics of food security in the Uruguay Round became more contentious. Despite the Montreal ministerial declaration's emphasis on developing countries' food security concerns, there was immediate pushback by a group of developed food-importing countries demanding that the negotiations address their food security concerns as well. Switzerland, Japan, and Norway pressed for food security to be taken into account as a non-trade concern in the agricultural negotiations (GATT, 1989b). Non-trade concerns refer to the multiple functions of an economic activity, including its commercial and non-commercial aspects (Smith, 2000). In the case of agriculture, the most often cited non-trade concerns are food security, rural livelihoods, and environmental stewardship. Supporters of food security as a non-trade concern called for trade rules to provide flexibility to meet these other functions, including lesser commitments to liberalize agriculture. Most contracting parties accepted this perspective and, in order to placate the concerns of developed countries, there was agreement in 1989 to also incorporate food security as a non-trade concern in the round, stating:

Participants recognize that factors other than trade policy are taken into account in the conduct of their agricultural policies. In the negotiations to achieve the long-term objective, account will be taken of proposals aimed at addressing participants' concerns such as food security. (GATT, 1989a: 11)

In addition to already committing to address the impacts of trade liberalization on net-food importing developing countries, the inclusion of food security as a non-trade concern inserted a broader conception of food security into the negotiations that included consideration of its commercial and non-commercial qualities. This particular framing of food security, alongside the debate between free trade versus food self-sufficiency, would also significantly shape the food security-related negotiating agenda during the Uruguay Round. 
Concerns about the possible negative effects for net-food importers became the basis for a new developing country bargaining coalition in the agriculture negotiations. Led by Egypt and referred to as the net-importers group (NIG), this bargaining coalition included Mexico, Jamaica, Peru, Morocco and claimed wide support among many developing countries. In the negotiations, the NIG pointed to the increase in world food prices between 1987 and 1989 as proof of the continued volatility in international food supply and the significant budgetary challenge for these countries in maintaining food imports (Egypt, 1989). These countries' bargaining position was informed by the prevailing consensus among economists at the time that predicted higher future food prices as a result of trade liberalization proposed in the round (GATT, 1990b; Ballenger and Mabbs-Zeno, 1992; Onyejekwe, 1993; Matthews, 1994; Winters, 1994: 157-158). Higher food prices, after all, was one the desired outcomes of the round for agricultural exporters, especially in the wake of the US-EC subsidy war and the cycle of farm crises. A key demand of the NIG was for the negotiations to address rising food prices and the associated balance of payments problems this was expected to create, including calling for the provision of financial compensation from developed countries to cover the cost of rising food import bills (Knudsen, 1990). In addition, the NIG demanded financial assistance from developed countries earmarked for increasing the production of basic foodstuffs essential for food security.

Whereas the NIG group made demands for compensation, other developing country GATT members sought additional trade flexibilities for food security. Other net-food importing countries, such as Honduras and El Salvador, raised specific concerns about the unpredictable effects of trade liberalization on the domestic production of traditional foodstuffs (i.e., pulses, white corn, roots and tubers) that were critical to the food security of poor and indigenous communities. Central American countries advanced two food security proposals. The first called for additional, transitory measures to allow for gradual adjustments to a more open trading environment. Given uncertainty about the future, these countries proposed that all developing countries be allowed to implement agricultural safeguards to avoid the flooding of their markets by related commodities, such as US maize (yellow corn) displacing domestic white corn (i.e., the traditional staple food in the region) (GATT, 1990b). However, this proposal did not gain wide acceptance and was not given further consideration. In a second proposal, Central American countries demanded the continued right of developing countries to use agricultural export 
prohibitions "in order to safeguard their food security in the event of shortfalls in the world supply of basic foodstuffs" (CACM Member Countries, 1990). Central American countries had by this time transitioned from food exporters to importers (similarly to many African countries). Food security was a sensitive political issue for these countries with large rural populations and characterized by significant instability in the countryside due to civil war and political conflicts. The proposal to retain export restrictions for food security purposes was in sharp contrast to the preference of the US to eliminate agricultural export restrictions and prohibitions.

While food exporters recognized the legitimacy of the food security concerns expressed by net-food importers, they were divided on how to address them. The US, Canada and Australia were uncomfortable with the idea of locking-in any commitments under the GATT framework to assist the NIG countries. This became a major point of contention between agricultural exporting developed countries and net-food importing developing countries during the course of the round. However, the negotiations on food security progressed steadily from 1989 to 1990, with the talks shifting from an emphasis on monetary compensation towards addressing rising food bills through a GATT administered policy framework (Egypt, 1989; GATT, 1989c; 1990c).

On the issue of food security as a non-trade concern, a major sticking point in the round became establishing criteria for the measurement and categorization of the trade impacts of specific national agricultural policies to determine when non-trade concerns justified flexibility. A major divide remained among contracting parties over the extent to which non-trade concerns should be grounds for exemptions from reforming so-called restrictive trade policies, such as import controls and other tariff and non-tariff barriers to manage agricultural imports. Agricultural exporting countries, such as those in the Cairns Group, took a hard line on restrictive measures and iterated their position on non-trade concerns as follows:

The Cairns Group recognizes that proposals related to non-trade concerns such as food security need to be taken into account in negotiations to achieve the long-term objective [establishment of a fair and market-oriented agricultural trading system]...However, proposals which contemplate the long-term retention of restrictions and distortions clearly would be inconsistent with that objective.....The 
aim therefore should be to identify means to meet non-trade concerns which are not trade-distorting in nature. (Cairns Group, 1989: 2)

The statement captures one end of the free trade versus food self-sufficiency spectrum that shaped the negotiations. The idea of legally binding self-sufficiency ratios, a policy intended to institutionalize food security as a non-trade concern and allow certain countries to offer less agricultural market access, continued to be supported by South Korea, Japan and India. ${ }^{8}$ Netfood importers also supported the proposal since it was seen as reinforcing national policies to expand support to domestic food production capacity. The idea of binding self-sufficiency ratios under the GATT was emphatically rejected by the agricultural exporters. The US and the Cairns Group argued against food self-sufficiency, stating that such policies were ineffective, that they would directly damage the interests of trading countries and went against the objectives of the round which was to meaningfully liberalize agriculture (Cairns Group, 1989).

International food aid was also a major item in the negotiations. The central concern for food exporters was to ensure that the potential reductions to be made in agricultural export subsidies would not lead to the misuse of food aid as an alternative escape valve for agriculture surpluses. Similar to earlier GATT rounds, agricultural exporters made clear they were particularly concerned about the misuse of food aid by the US for commercial purposes. Under pressure, the US put forward a proposal to distinguish bona fide food aid from surplus disposal or market development. Contracting parties did raise concerns that agricultural trade liberalization under the Uruguay Round could lead to reduced international food aid supply, however, this aspect of food aid did not receive as much attention in the negotiations as exporters' concerns about competing with non-commercial food transactions. As a result, it has been argued that the concerns of food aid recipients were largely dismissed during the Uruguay Round (Hopkins, 1992).

\section{Food Security Negotiating Outcomes}

\footnotetext{
${ }^{8}$ Unlike the Kennedy Round, the EC in this instance was not a supporter of binding self-sufficiency ratios because by this point in time it had transitioned to a major food exporter, thus illustrating the changing composition of food exporters and importers over time.
} 
The results of the GATT Uruguay Round in agriculture are well known. The Agreement on Agriculture (AoA) fully incorporated agriculture under international trade rules after repeated failures in the previous GATT rounds (Stewart, 1999; Croome, 1999; Hoekman and Kostecki, 2001). The agreement included binding commitments to reduce agricultural subsidies and tariffs, with special and differential treatment for developing countries. The AoA initiated a long-term process of trade liberalization in agriculture, largely focused on reducing developed countries' subsidies and other forms of protectionism that were deemed to distort markets and prevent free trade. Moreover, the AoA was also critical in setting the course towards policy convergence in agriculture among developing and developed countries. There is a wide debate on the impacts, fairness, and effectiveness of the AoA. Rather than repeating this debate, my focus here is on examining how food security issues became codified into the rules of the trade system.

The extent to which the provisions of the AoA set out rules and commitments that applied specifically and directly to food security is underappreciated. In fact, a broad range of such provisions were included in the agreement. Food security was recognized as a non-trade concern in the agreement's preamble, which sought to address the concerns raised by developed country food importers by confirming these concerns as legitimate in principle but lacking specific rules. ${ }^{9}$ The agreement contained several food security provisions related to domestic support and export competition (listed in Table 1). On domestic support, the agreement includes, for example, specific food security-related rules in the so-called Green Box category of minimally trade-distorting support measures in Article 6 (i.e., measures classified under WTO rules as a form of direct government support that was understood to distort the functioning of self-correcting markets, but remained permissible under specific conditions and limits prescribed in the agreement). These are further specified in Annex 2 of the Agreement, which defines measures such as support for resource poor farmers, public food stockholding, direct food subsidies and domestic food assistance programs are permitted on food security grounds. In export competition, for example, Article 10.4 of the Agreement established new rules on international food aid, requiring that food aid not be tied to commercial sales and accord with the

\footnotetext{
${ }^{9}$ The preamble stated "Noting that commitments under the reform program should be made in an equitable way among all Members, having regard to non-trade concerns, including food security and the need to protect the environment; having regard to the agreement that special and differential treatment for developing countries is an integral element of the negotiations, and taking into account the possible negative effects of the implementation of the reform program on least-developed and net food-importing developing countries." (WTO, 2001a)
} 
rules set in the FAO Principles on Surplus Disposal and FAC. The main purpose of these rules being to prevent the dumping of surpluses as food aid. Article 10.4 is significant because although it built on existing rules in the FAO Principles and FAC, it resulted in a new form of issue-linkage between trade law and international food aid, with the WTO taking on the role of a centralizing institution because of its binding international law that hardened these other "soft law" international food aid agreements.

Table 1. Selected Food Security Provisions in the WTO Agreement on Agriculture

\begin{tabular}{|l|l|l|}
\hline Article & Item & Relevance to food security \\
\hline Article 6 & $\begin{array}{l}\text { Domestic Support } \\
\text { Commitments }\end{array}$ & $\begin{array}{l}\text { Describes permissible forms of government assistance to agricultural } \\
\text { and rural development, including domestic food aid and investment } \\
\text { subsidies and agricultural input subsidies targeted at low-income or } \\
\text { resource-poor (i.e., food insecure) producers in developing countries. }\end{array}$ \\
\hline Article 10.4 & International Food Aid & $\begin{array}{l}\text { Establishes the criteria for differentiation between legitimate } \\
\text { international food aid and disguised government export subsidies. }\end{array}$ \\
\hline Article 12 & $\begin{array}{l}\text { Disciplines on Export } \\
\text { Prohibitions and }\end{array}$ & $\begin{array}{l}\text { Sets out consultation process for implementation of export restriction } \\
\text { or prohibitions permitted to relieve critical shortages of foodstuffs or } \\
\text { essential products. }\end{array}$ \\
\hline Article 16 & $\begin{array}{l}\text { Least-Developed and } \\
\text { Det Food-Importing }\end{array}$ & $\begin{array}{l}\text { Refers to the obligations under the Decision on Measures Concerning } \\
\text { the Possible Negative Effects of the Reform Programme on Net-Food- } \\
\text { Importing Countries. }\end{array}$ \\
\hline $\begin{array}{l}\text { Annex II, } \\
\text { Paragraph 3. }\end{array}$ & $\begin{array}{l}\text { Public Food } \\
\text { Stockholding For Food } \\
\text { Security }\end{array}$ & $\begin{array}{l}\text { Specifies the conditions under which governments may accumulate } \\
\text { and hold stocks of agricultural products that form an integral part of a } \\
\text { food security programme. }\end{array}$ \\
\hline $\begin{array}{l}\text { Annex II, } \\
\text { Paragraph 4. }\end{array}$ & Domestic Food Aid & $\begin{array}{l}\text { Establishes requirements that domestic food aid programs established } \\
\text { clearly-defined criteria nutritional objectives and conditions for eligibility } \\
\text { for recipients to buy food either at market or below-market prices. }\end{array}$ \\
\hline
\end{tabular}

The most significant negotiating outcome of the Uruguay Round for food security was a side-agreement to address the concerns of net-food importers referenced in Article 16 of the AoA - the Decision on Measures Concerning the Possible Negative Effects of the Reform Programme on Net-Food-Importing Countries (known as the Marrakech Decision). The Marrakech Decision represented a compromise between the US/EC and the NIG, and required WTO trade ministers to formally recognize that trade liberalization could lead to higher world food prices. It committed them to reviewing the level of international food aid at the WTO and providing favorable financing for food purchases and technical assistance to affected countries (WTO, 
1994c). At the time, net-food importing developing countries saw this as a very significant agreement; it was a guarantee of a food security safety-net measure in exchange for their acceptance the US-EC proposal on agriculture, which was pivotal to securing broad agreement to conclude the negotiations. Following the end of the Uruguay Round, there has been debate among WTO members about the obligations set out in the Marrakech Decision and its legal status as a "decision" rather than an "agreement". Framing this is a "decision" reflected a compromise by agricultural exporters to ensure it did not have the same legal status as an agreement while this satisfied net-importers preference to ensure decision-making remained within the trade regime.

Taken together, the food security provisions in the AoA and the Marrakech Decision marked a significant juncture from earlier GATT rounds by codifying food security into the rules and practices of the multilateral trade system. This also had the effect of formalizing the authority of the WTO in global food security governance, as it rules are legally binding under international law when most other international food security agreements under the FAO, FAC and WFP are non-binding, soft-law arrangements.

\section{Implementing Food Security in the WTO}

The key food security debate in the implementation phase of the Uruguay Round agreement revolved around the Marrakech Decision. Following the establishment of the WTO in 1995, there were several episodes of high food prices (FAO, 1999a; Sharma and Konandreas, 2008). During these episodes, net-food importers called for the implementation of the Marrakech Decision, demanding that developed countries provide them with assistance in times of high food prices. However, the US, Canada, and Australia resisted efforts to implement the Marrakech Decision, justifying their position by arguing that it was impossible to empirically demonstrate that higher food prices were directly related to trade liberalization under the AoA rather than other market factors. In addition, the years following the establishment of the WTO saw a sharp decline in the volumes of international food aid provided, which some analysts partially attributed to the Uruguay Round agricultural reforms (Clay and Stokke, 2000: 31). At the 1996 Singapore WTO Ministerial, developing countries sought to bring greater attention to food security issues, unsuccessfully calling for a working group on trade and food security to be 
established in order to explore implementation issues affecting food insecure developing countries. By this time WTO members had come to see the Marrakech Decision as a "paper tiger" and net-food importers claimed that this represented a broken promise by developed countries to meet the spirit of the Marrakech Decision (WTO, 2001d; FAO, 1999a). ${ }^{10}$

\section{Conclusion}

As this article has shown, disagreement over food security issues is not a new or distinctive feature of the WTO Doha Round. Rather, inter-state disagreements on how to address food security in trade negotiations have a long history dating back to the Havana Charter negotiations in 1947. At the same time, the GATT has been an important forum for inter-state cooperation on food security. This is most evident in the instances of agreement, ranging from GATT monitoring of food aid in the Dillon Round to the negotiation of the FAC during the Kennedy Round. A historically-informed analysis of food security in multilateral trading negotiations shows important parallels between the past and present. Food security issues that have been key points of conflict in the Doha Round - including international food aid, export restrictions, food stockholding and agricultural safeguards - have all been the cause of inter-state disagreement in previous trade rounds. Another important parallel is the role of external events in shaping multilateral trade negotiations. For example, the GATT Tokyo Round and the WTO Doha Round both saw the negotiating agenda on food security expanded, and inter-state disagreement become more pronounced, in response to world-scale food crises. A final discernible parallel is the continuing divide between net-food exporting and importing countries with respect to broadly conflicting perspectives on the relationship between international trade and food security in multilateral trade negotiations. However, the parameters of this divide have changed significantly over time. During the Dillon and Kennedy round negotiations, the main divide was between a small group of agricultural exporting countries (i.e., US, Canada and Australia) and net-food importers such as the EC and Japan. From the Tokyo round onwards, the group of netfood exporting countries has become larger and more diverse - it now encompasses a wider range of countries including the US, EC, Canada, Brazil, Thailand, and others - at the same time that an increasing number of developing countries have transitioned from net-food exporters to

\footnotetext{
${ }^{10}$ Confidential interviews with developing and developed country officials, Geneva, April 2009.
} 
net-food importers and are concerned about their vulnerability to food price volatility and supply shocks. ${ }^{11}$ The GATT's bargaining history also shows that the perspectives and problems that have informed the negotiations on food security in the multilateral trading system are not consistent over time but fluid, responding to changing conditions in the world economy and states' own perceptions of their relative national food security/insecurity status at different points in time.

Taking a longer-term, historical view of the agendas and outcomes of successive GATT negotiations, we see that food security has been slowly but steadily integrated into the trade regime over time. The conclusion of the Uruguay Round was a pivotal development in this regard in that it marked the codification of food security issues into the trade regime, resulting in the WTO covering a much wider range of agriculture and food security policies (i.e., domestic and international food aid, food stockholding, and special provisions for net-food importing developing countries). This marked a change from the Kennedy and Tokyo rounds when the implementation and governance of food security issues were shifted out of the trade regime into other institutions such as the UN. Today, due to the codification of food security into the rules of the multilateral trading system, the WTO's rules are highly consequential for domestic and international food security policymaking. As a result, the WTO now plays a considerable role in global food security governance. This article has thus shown the need to be attentive to the history of food security in multilateral trade negotiations that predated and shaped the Doha Round.

\footnotetext{
${ }^{11}$ For a discussion on the changing taxonomy of net-food importing developing countries see Valdés and Foster (2012).
} 


\section{Works Cited}

Abbott, Philip C. 2012. Export Restrictions as Stabilization Responses to Food Crisis. American Journal of Agricultural Economics 94(2): 428-434.

Anderson, Kym, Gordon Rausser and Johan Swinnen. 2013. "Political Economy of Public Policies: Insights from Distortions to Agricultural and Food Markets. Journal of Economic Literature, 51(2): 423-77.

Argentina. 1965. Proposal for a World Food Fund. Geneva: GATT.

Ballenger, Nicole, and Carl Mabbs-Zeno. 1992. Treating Food Security and Food Aid Issues at the GATT. Food Policy 17 (4):264-276.

Bergesen, Helge Ole. 1980. A New Food Regime: Necessary but Impossible. International Organization 34 (2):285-302.

Bezemer, Drik and Headey, Derek. 2008. Agriculture, development, and urban bias. World Development, 36(8): 1342-1364.

Cairns Group. 1989. Comprehensive Proposal for the Long-Term Reform of Agricultural Trade: Submission by the Cairns Group Comprising Argentina, Australia, Brazil, Canada, Chile, Colombia, Hungary, Indonesia, Malaysia, New Zealand, Philippines, Thailand and Uruguay. Geneva: GATT.

Canada. 1974. Group 3(e): Work on Task 4 Views Submitted by Delegations. Addendum. Geneva: GATT.

Candel, Jeroen. 2014. Food Security Governance: A Systematic Literature Review. Food Security 6(4):585-601.

Cardwell, Ryan, and William A. Kerr. 2014. Can Export Restrictions be Disciplined Through the World Trade Organisation? The World Economy 37(8):1186-1196.

Central American Common Market (CACM) Member Countries. 1990. Uruguay Round Negotiations on Agriculture: Proposals by CACM Member Countries. Geneva: GATT. Clapp, Jennifer. 2004. "WTO agricultural trade battles and food aid." Third World Quarterly 25 (8): 1439-1452.

Clapp, Jennifer. 2013. Hunger in the Balance: The New Politics of International Food Aid. Ithaca: Cornell University Press. 
Clapp, Jennifer and Cohen, Marc J. (eds.). 2009. The Global Food Crisis: Governance challenges and opportunities. Waterloo: Wilfrid Laurier University Press.

Clay, Edward J., and Olav Stokke, eds. 2000. Food Aid and Human Security. Portland: Frank Cass Publishers.

Cohn, Theodore. 1979. The 1978-9 Negotiations for an International Wheat Agreement: An Opportunity Lost? International Journal 35 (1):132-149.

Coleman, William D., 1998. From protected development to market liberalism: paradigm change in agriculture. Journal of European Public Policy, 5(4): 632-651.

Croome, John. 1999. Reshaping the World Trading System: A History of the Uruguay Round. Waterloo: Kluwer Law International.

De Schutter. 2011. The World Trade Organization and the Post-Global Food Crisis Agenda: Putting Food Security First in the International Food System. Accessed 10 January 2016. Available at: http://www.srfood.org/images/stories/pdf/otherdocuments/20111116_briefing_note_05_e $\underline{\text { n.pdf }}$

De Souza Farias, Rogério. 2013. Mr GATT: Eric Wyndham White and the Quest for Trade Liberalization. World Trade Review 12(3) 463-485.

Drache, Daniel. 2000. The Short but Amazingly Significant Life of the International Trade Organization (ITO): Free Trade and Employment: Friends or Foes Forever? Toronto: Robarts Centre

Drèze, Jean, and Amartya Sen, eds. 1991. Hunger and Public Action. Oxford: Oxford University Press.

Egypt. 1989. Statement Made by the Delegation of Egypt on Behalf of a Number of Net FoodImporting Developing Countries: Elements to Take into Account the Negative Effects of the Reform Process on the Net Food-Importing Developing Countries. Geneva: GATT. European Economic Community (EEC). 1975. Statement Made by the Representative of the European Economic Community 17 May 1975. Geneva: GATT.

Farsund, Arild Aurvåg, Carsten Daugbjerg, and Oluf Langhelle. 2015. Food security and trade: Reconciling discourses in the Food and Agriculture Organization and the World Trade Organization. Food Security, 7(2): 383-391. 
Finger, J. Michael. 1974. Tariff Concessions and the Exports of Developing Countries: United States Concessions at the Dillon Round. The Economic Journal 84 (335):566-575.

FAO. 1999. Report on Technical Assistance Related to the Uruguay Round. Rome: FAO. FAO. 2003. Trade Reforms and Food Security: Conceptualizing the Linkages. Rome: FAO. FAO. 2009. The State of Food Insecurity in the World 2009. Rome: FAO.

Friedmann, Harriet. 1982. The Political Economy of Food: The Rise and Fall of the Post-war International Food Order. The American Journal of Sociology 88:248-286.

GATT. 1958. Expansion of International Trade: Decision of 17 November 1958 and Appointment of Committees. 27 November 1958. Geneva: GATT.

GATT. 1961a. Meeting of Ministers: Proposals for Agenda. Geneva: GATT.

GATT. 1961b. Third Report of Committee II: Note by the Chairman. Geneva: GATT.

GATT. 1962. Disposal of Commodity Surpluses: Reports by Contracting Parties. Geneva: GATT.

GATT. 1967. Elements for an International Wheat Agreement. Geneva: GATT.

GATT. 1973a. Statement of Ministers. Geneva: GATT.

GATT. 1973b. Proceedings of the First Meeting Held in the Palais des Nations. Geneva: GATT. GATT. 1974a. Group 3(e): Report to the Trade Negotiations Committee. Geneva: GATT.

GATT. 1974b. Group 3(e): Consideration of Technical Work to be Undertaken (Note by the Secretariat). Geneva: GATT.

GATT. 1974c. Group 3(e): Points Relating to Programme of Work (Note by the Secretariat) Geneva: GATT.

GATT. 1974d. Group 3(e): Meeting of April 1974 Geneva: GATT.

GATT. 1974e. Group 3(e): Work on Task 4. Key Points Made at the Meeting of April 1974 (Note by the Secretariat) Geneva: GATT.

GATT. 1975a. Sub-Group on Grains: List of Representatives. Geneva: GATT.

GATT. 1975b. Summing-Up by the Acting Chairman. Geneva: GATT.

GATT. 1985. Summary of Points Raised at the Meeting of the Committee Held on 2-3 April 1985 (Note by the Secretariat). Geneva: GATT.

GATT. 1986c. Observer Status in GATT: Note by the Secretariat. Supplement Geneva: GATT. 
GATT. 1988a. Eight Meeting of the Negotiating Group on Agriculture (Note by the Chairman). Geneva: GATT.

GATT. 1988b. Summary of the Main Points Raised at the Eighth Meeting of the Negotiating Group on Agriculture. Geneva: GATT.

GATT. 1988c. Negotiation Group on Agriculture: Proposal by Egypt, Jamaica, Mexico and Peru Geneva: GATT.

GATT. 1988d. Trade Negotiations Committee Meeting at Ministerial Level Geneva: GATT.

GATT. 1989a. Trade Negotiations Committee: Eighth Meeting. Geneva: GATT.

GATT. 1989b. Mid-Term Meeting. Geneva: GATT.

GATT. 1990b. Working Paper Submitted by Egypt, Jamaica, Morocco and Peru: Uruguay Round Window for Net Food Importing Developing Countries Geneva: GATT.

GATT. 1993. An Analysis of the Proposed Uruguay round Agreement, with Particular Emphasis on Aspects of Interest to Developing Economies. Geneva: GATT.

Gilbert, Christopher, L. 1987. International commodity agreements: design and performance. World Development, 15(5), pp.591-616.

Häberli, Christian. 2012. The WTO and Food Security: What's Wrong with the Rules? In Rosemary Rayfuse and Noicole Weisfelt (eds), The Challenge of Food Security: International Policy and Regulatory Frameworks. Cheltenham and Northampton: Edward Elgar, 149-167.

Hedges, Irwin R. 1967. Kennedy Round Agricultural Negotiations and the World Grains Agreement. Journal of Farm Economics 49 (5):1332-1341.

Hirschman, Albert O., 1977. A generalized linkage approach to development, with special reference to staples. Economic Development and Cultural Change, 25(Supplement) p.6797.

Hoekman, Bernard M., and Michael M. Kostecki. 2001. The Political Economy of the World Trading System: The WTO and Beyond. Oxford: Oxford University Press.

Hopewell, Kristen, 2016. The accidental agro-power: constructing comparative advantage in Brazil. New Political Economy (Online First).

Hudec, Robert E., 1987. Developing countries in the GATT legal system. Cambridge: Cambridge University Press. 
India. 1967. Communication from the Government of India. Geneva: GATT.

India. 1976. Statement Made by the Representative of India on 29 January 1976. Geneva: GATT. Japan. 1988. Statement by Japan in the Negotiating Group on Agriculture. Geneva: GATT.

Josling, Timothy E. 1985. International Agriculture Policy: A Role for National Food

Programmes? In Agriculture and International Relations: Analysis and Policy, edited by H. De Haen, G. L. Johnson and T. E. Josling. London: McMillan.

Josling, Timothy E., Stefan Tangermann, and K.T. Warley. 1996. Agriculture in the GATT. Basingstoke: Palgrave Macmillan

Knudsen, Odin. 1990. Food Security and compensation: the Role of the GATT. The GATT, Agriculture and the Developing Countries, Nurul Islam and Alberto Valdés (eds). Washington: IFPRI, pp.33-38.

Kripke, Gawain. 2015. Food fight: What the debate about food security means at the WTO. Canadian Food Studies/La Revue canadienne des études sur l'alimentation 2(2): 77-87.

Krueger, Anne O., Maurice Schiff and Alberto Valdés. 1988. Agricultural incentives in developing countries: Measuring the effect of sectoral and economy wide policies. The World Bank Economic Review, 2(3): 255-271.

Krueger, Anne O. 1998. The WTO as an International Organization. Chicago: University of Chicago Press.

Koffsky, Nathan M. 1967. The Food Potential of Developing Nations. Journal of Farm Economics 49 (5):1106-1113.

Lamond, Alan R. 1977. The UNCTAD Integrated Programme for Commodities and the World Food Problem. World Development 5 (5-7):595-601.

Lamp, Nicolas. 2015. How Some Countries Became 'Special': Developing Countries and the Construction of Difference in Multilateral Trade Lawmaking. Journal of International Economic Law, 18(4), pp.743-771.

Lamy, Pascal. 2011. Lamy rebuts UN food rapporteur's claim that WTO talks hold food rights 'hostage,'4 December. Accessed 10 January 2016. Available at: https://www.wto.org/english/news_e/news11_e/agcom_14dec11_e.htm 
Margulis, Matias E. 2009. Multilateral Responses to the Global Food Crisis. Perspectives in Agriculture, Veterinary Science, Nutrition and Natural Resources, 4(12): 1-10.

Margulis, Matias E. 2013. The regime complex for food security: implications for the global hunger challenge. Global Governance: A Review of Multilateralism and International Organizations, 19(1):53-67.

Margulis, Matias E. 2014a. "The World Trade Organization and Food Security after the Global Food Crises." Pp. 236-55 in Linking Global Trade and Human Rights: New Policy Space in Hard Economic Times, edited by Daniel Drache and Lesley Jacobs. New York: Cambridge University Press.

Margulis, Matias E. 2014b. Trading Out of the Global Food Crisis? The World Trade Organization and the Geopolitics of Food Security. Geopolitics 19(2): 322-350.

Martin, Will and Kym Anderson. 2012. Export Restrictions and Price Insulation During Commodity Price Booms. American Journal of Agricultural Economics 94(2): 422-427

Matthews, Alan. 1994. Food Security and the GATT: A Neglected Agenda. Troicare Development Review: 85-96.

Matthews, Alan. 2014. Trade Rules, Food Security and the Multilateral Trade Negotiations. European Review of Agricultural Economics 41(3): 511-535.

Maxwell, Simon and Rachel Slater. 2003. Food policy old and new. Development Policy Review 21(5-6): 531-553.

Melendez-Ortiz, Ricardo, Christopher Bellmann, and Jonathan Hepburn. 2009. Agricultural Subsidies in the WTO Green Box: Ensuring Coherence with Sustainable Development Goals. Cambridge: Cambridge University Press.

Murphy, Sophia. 2015. Food Security and International Trade: Risk, Trust and Rules. Canadian Food Studies/La Revue canadienne des études sur l'alimentation 2(2): 88-96.

Norwood, Bernard. 1969. The Kennedy Round: A Try at Linear Trade Negotiations. Journal of Law and Economics 12 (2):297-319.

Onyejekwe, Kele. 1993. GATT, Agriculture, and Developing Countries. Hamline Law Review 17:77-153.

Pauwelyn, Joost. 2005. The Transformation of World Trade. Michigan Law Review 104(1): 165. 
Paarlberg, Robert, 1997. Agricultural policy reform and the Uruguay Round: Synergistic linkage in a two-level game? International Organization, 51(03): 413-444.

Pinstrup-Andersen, Per. 2009. Food Security: Definition and Measurement. Food Security 1(1): $5-7$.

Raffaelli, Marcelo. 1995. Rise and Demise of Commodity Agreements: An Investigation into the Breakdown of International Commodity Agreements. Cambridge: Woodhead Publishing.

Rehm, John B. 1968. Developments in the Law and Institutions of International Economic Relations: The Kennedy Round of Trade Negotiations. The American Journal of International Law 62 (2):403-434.

Rao, J. Mohan, 1986. Agriculture in recent development theory. Journal of Development Economics, 22(1): 41-86.

Ross, Sandy. 2011. The World Food Programme in Global Politics. Boulder: FirstForumPress.

Scott, James. 2010. Developing Countries in the ITO and GATT Negotiations. Journal of International Trade Law and Policy 9(1):5-24.

Sharma, Ramesh, and Panos Konandreas. 2008. WTO Provisions in the Context of Responding to Soaring Food Prices. In FAO Commodity and Trade Policy Research Working Paper No. 25. Rome: FAO.

Shaw, D. John. 2007. World Food Security: A History Since 1945. London: Palgrave Macmillan.

Skogstad, Grace. 1998. Ideas, paradigms and institutions: agricultural exceptionalism in the European Union and the United States. Governance, 11(4): 463-490.

Staples, Amy L. 2003. To Win the Peace: The Food and Agriculture Organization, Sir John Boyd Orr, and the World Food Board Proposals. Peace \& Change 28(4):495-523.

Stewart, David P. 1999. The GATT Uruguay Round: A Negotiating History (1986-1994). Waterloo: Kluwer Law International.

Stewart, Terence P., and Stephanie Manaker Bell. 2014. Global Hunger and the World Trade Organization: How the International Trade Rules Address Food Security. Pennsylvania State Journal of Law and International affairs 3(2): 113-155.

Swinbank, Alan and Tanner, Carolyn, 1996. Farm policy and trade conflict: the Uruguay Round and CAP reform. University of Michigan Press. 
Timmer, C. Peter. 2010. Reflections on food crises past. Food Policy 35(1):1-11.

Trebilcock, Michael J., and Robert Howse. 2005. The Regulation of International Trade. Third ed. London: Routledge.

United Nations (UN). 1948. Havana Charter for an International Trade Organization. UN.

UN. 1974. Report of the World Food Conference. 5-16 November 1974. Rome: UN.

United States (US) 1958. Plans for New Tariff Negotiations: Proposal by United States

Delegation 1 November. Geneva: GATT.

US. 1966. Telegram From the Mission in Geneva to the Department of State. Geneva, July 29.

Available at: https://history.state.gov/historicaldocuments/frus1964-68v09/d324

US. 1974. Opening statement at Meeting of group 3(e) 2 April 1974 Geneva: GATT.

US. 1976. Statement made on 25 May 1976. Geneva: GATT.

US. 1988. Elaboration of US Agricultural Proposal with Respect to Food Security. Geneva: GATT.

Valdés, Alberto and Foster, William. 2012. Net Food-Importing Developing Countries: Who They Are, and Policy Options for Global Price Volatility. ICTSD Programme on Agricultural Trade and Sustainable Development Issue Paper No. 43. Geneva: International Centre for Trade and Sustainable Development.

Winters, L. Alan. 1994. The LDC perspective. In Agriculture in the Uruguay Round, K.A. Ingersent, A.J, Rayner and R.C. Hine (eds). Basingstoke: Palgrave Macmillan UK, pp. 157-181.

Wilkinson, Rorden, and James Scott. 2008. Developing country participation in the GATT: a reassessment. World Trade Review 7(3): 473-510.

Wilkinson, Rorden, Erin Hannah, and James Scott. 2014. The WTO in Bali: What MC9 Means for the Doha Development Agenda and Why It Matters. Third World Quarterly 35(6): 1032-1050.

Williamson, John, 2009. A Short History of the Washington Consensus. Law and Business Review of the Americas, 15: 7-23.

Wolfe, Robert. 1998. Farm Wars: The Political Economy of Agriculture and the International Trade Regime. Basingstoke: Macmillan. 
Wolfe, Robert. 2009. The Special Safeguard Fiasco in the WTO: The Perils of Inadequate Analysis and Negotiation. World Trade Review 8(4):517-544.

WTO. 1994a. Agreement on Agriculture. Geneva: GATT.

WTO. 1994c. An Analysis of the Proposed Uruguay Round Agreement, with Particular Emphasis on Aspects of Interest to Developing Economies. Geneva: GATT.

WTO. 2001. Doha Ministerial Declaration. Geneva: WTO. 